Research.

\title{
Intervening effect of personal value on the code of ethics to ethical judgment
}

\author{
Yuli Anwar \\ Department of Accounting, Universitas Binaniaga Indonesia, Bogor, Indonesia \\ juli_anwar@yahoo.com (Y. Anwar) \\ Received: March 11, 2020; Accepted: April 25, 2020; Published: June 30, 2020. \\ To cite this article: Anwar, Y. (2020). Intervening effect of personal value on code of ethics to ethical judgment. \\ The Accounting Journal of BINANIAGA. 5 (1): 19-32. doi: $\underline{10.33062 / a j b . v 5 i 01.365}$

\begin{abstract}
The purpose of this study is to examine and analyze empirically the effect of code of ethics understanding to ethical judgment through personal value of public accountant. The model proposed in this research was tested by means of structural equation modeling. The data were collected from purposive sampling and the number of samples of this research were 301 partners, manager, supervisor, and senior accountant in Indonesia. Construct that directly affect each other in this study are code of ethic to personal values and code of ethic to ethical judgment and and prove that personal value is an intervening variable. The model proposed in the research shows the impact code of ethics, personal value and ethical judgment. Future research should study of morality of auditor and collected sample from Asian countries. Partner, manager, supervisor, and senior auditor may take a decision wiser with ethical judgment with based on fact. The model proposed in this research partner, manager, supervisor, and senior auditor have positive direct impact of each code of ethic to personal values and positive direct impact code of ethic to ethical judgment.
\end{abstract}

Keywords: Code of Ethics, Personal Value, Ethical Judgment

\section{INTRODUCTION}

The biggest public accountant in the world had done the scandals, Arthur Andersen has jeopardized and decreased even eliminated the people trust upon moral, personal value, ethics and independence of public accountant. The failure of Athur Andersen has vanished the people trust upon the honesty and standard of professional ethics (Coleman, Kreuze and Langsam, 2004).

Recent business evolvement has required public accountant to deal with the ethical dilemma, which is sometimes involving the value of the ethics. The ethical dilemma refers to setting auditing, it could happen, when the public accountant had disagreed with the client requirement regarding the functional aspects and the objective of an audit. In this case, public accountant can be influenced by the client to perform a serial of auditing execution, which is against the auditing standard. However, in fact, since public accountants have been following the professional ethics and auditing standard, they will be put into a conflict situation performing their tasks accordingly. It means when they should have to be agreed with the client requirement, they had broken the auditing standard regulation. Nevertheless, when they did not follow the client request, they would receive a serious sanction, which is stopping the job (Muawanah and Indriantoro, 2001).

\section{Ethical Judgment}

The ethical judgement of public accountant is obviously an important role of the accountancy skills implementation. Public Accountants have been usually 
encountering an ethical dilemma when they have to deal with a doubtful ethical judgement refers to the standard of moral and ethical judgement of their own affecting their judgment and behavior (Jones, 1991). Wrigth et al., (1997) have investigated the preferences of public accountant value and their research has complied with the hypothesis determined which is the effect of the value of moral intensity.

Shafer et al., (2001) targeted public accountant in their research related to the effect of personal value upon the ethical decision-making. The research has determined that the personal value of public accountant has not influenced how public accountants handling the problem of ethical dilemma (including the pressure from the clients). Some studies have discussed the same problems, but they have not considered the effect of moral philosophy and social responses accordingly. (Wrigth et al., 1997; Shafer et al., 2001; Karacaer et al., 2009).

The research done by Kung, Fan-Hua and Cheng Li Huang (2013), defined that the preference of the value has failed to be a predictor of ethical beliefs. On the contrary, personal value has affected the ethical beliefs thru moral philosophy. Moreover, accountants have been motivated by the value of negative selfimprovement related to ethical idealism and the positive one related to relativism. Therefore, it can be concluded that the idealist accountants have tended to curse the clients who have broken moral norms, but relativist ones have been more permissive.

Wiratama and Budiartha (2015) described that accountants having an opini upon the reliability of the financial report are obliged to be independent on behalf of all related parity requirements. The accountants should have to be honest either to the internal or external party relying on the financial report audited. The independent accountant is very crucial to be respected, because once the client had not trusted the auditing report done by an auditor, the client or third party would ask no morefurther assistance from the related auditors. As it is stated in the Codes of Ethics of Professional Public Accountant, an accountant is obliged to respect the codes of ethics and to get rid of any misperception of the people regarding the independence of public accountant. People opinion regarding the accountant independence are due to an intrinsic independence related to the personal value instead of the regulation regulated and evaluated objectively. As long as this kind of independence perception is within the professional codes of ethics, it will make accountants to execute their tasks as independent as possible according to the professional regulation. Based on the explanation above, the following hypothesis is proposed:

$\mathrm{H} 1$ : codes of ethics affect to ethical judgement through personal value.

\section{Codes of Ethics}

Nur, Emrinaldi (2014) determined that nowadays, the accountants who have implemented the professional codes of ethics having good competency and experience, their opinions are reliable. However, the audit situation has not had any significant connection with the truth of the opinion provided. In Indonesia, the issues regarding the accountant ethics have been come up in line with some ethics violations happened due to either being done by public accountant, internal accountant or administrative accountant. Such a behavior does not comply with the professional accountant codes of ethics that should not have to be happened since it is jeopardizing the people trust upon the professional accountants.

Booth and Schulz (2004), discovered that strengthening the codes of ethics has been affecting significantly the manager behavior. However, (Brief, et al., 1996) determined that no any significant effect of codes of ethics would happen if it had been applied without reinforcement effort. Pflugrath (2007) identified that the existence of codes of ethics has affected positively upon the judgement quality done by public accountant. Moreover, previous researches about codes of ethics have identified that codes of ethics have influenced absolutely the auditor's ethical judgment. (Jones, et 
al., 2003; Herron and Gilbertson, 2004). Based on the explanation above, the following hypothesis is proposed:

H2: codes of ethics affect to ethical judgment.

\section{Personal value}

The research done by Akaah and Lund (1994) and Finegan (1994) declared that there is not any significant effect happened between the personal value and the ethical judgement refers to the organizational context. However, the research done by $\mathrm{Au}$ and Wong (2000), Abdolmohammadi and Baker (2005), indicated that a significant effect between personal value and ethical judgement has happened accordingly. Alteer, et al., (2013), has revealed that some models of ethical theory have provided a significant understanding about the ethical issues and some factors influencing the ethical judgement. The other model is accountant ethical judgement, which has been influenced by personal value thru the sensitivity of ethics. However, the effect of personal value on the ethical sensitivity is expected to be stronger at the level of ethical climate. Nevertheless, Shafer, et al., (2001) defined that the preferences of personal value did not absolutely affect the perception of public accountant refers to moral intensity of ethical dilemma.

In reference with the discrepancies of the previous research done by some researchers such as Nur, Emrinaldi (2014) determined that the more respect to the codes of ethics happened, the more accurate opinion would be; Booth and Schulz (2004) determined that strengthening codes of ethics has been producing a significant impact; Pflugrath (2007) declared that the existence of codes of ethics has positively affected the quality of judgement, Jones, et al, (2003); Herron and Gilbertson (2004) determined that an ethics can influence the auditor's ethical judgement, and Brief, et al. (1996) determined that there is not any significant effect happened when codes of ethics had been introduced without using a reinforcement effort. Akaah and Lund (1994) and Finegan (1994) determined that there has not been any significant effect happened between the personal value and the ethical judgement, Au and Wong (2000); Abdolmohammadi and Baker (2005) indicated a significant effect has happened between personal value and ethical judgement, Alteer, et al, (2013) indicated that the ethical judgement of an accountant has been affected by personal value thru ethical sensitivity, and Shafer, et al, (2001), determined that the preference of personal value has not affected the perception of public accountant.

However, nowadays there are so many ethical violations have been occurred either they have been conducted by public accountant, internal accountant, government accountant or the offices of public accountant, so that, this research aims to make over the related discrepancies by studying either a direct effect or an indirect effect of the codes of ethics upon the ethical judgment intervened by the personal value. Based on the explanation above, the following hypothesis is proposed:

H3a: codes of ethics affect to personal value.

H3b: personal value affect to ethical judgement.

\section{METHOD}

\section{Sample and Procedure}

Samples selection of this research has been done gradually. First step is finding out the location of the research. The location of the research has been done at the big five of the cities in Indonesia which is Jakarta, Bandung, Medan, Semarang and Surabaya by considering as follows; Firstly, those big five of the cities have 367 offices of public accountant (KAP) (Jakarta $=258$, Bandung $=30$, Medan $=19$, Semarang $=17$, and Surabaya $=43)$ or $83.32 \%(367 / 525)$ of the total KAP in 
Indonesia registered in the Directory of the Indonesian Public Accountant in 2016. Secondly, it is related to the total of the partners, managers, supervisors and senior auditors at those five cities, which have considerably represented the partners, managers, supervisors, and senior auditors in Indonesia. Thirdly, limitation of time and cost consumed is the problem of the writer to face reaching all the area of the research.

Second step of sampling selection is to decide the total of the samples. Defining the total of the samples is based on the size of the samples required refers to the data analysis applying a structural equation model. Referring to Ghozali (2011) total of the samples required is the maximum likelihood estimation using structural equation model, which is between 200 to 400 respondents. Based on the aforementioned guideline, the total of the samples required is between 200 to 400 respondents. The samples selected comply with the related requirement representing the population accordingly. Furthermore, sampling collection has been using the method of purposive sampling. This method has been chosen due to, (1) samples of the research are having the status as partners, managers, supervisors, and senior auditors, (2) total offices of public accountant in Indonesia are centralized at some big cities only, which is Jakarta $(49.14 \%)$, Bandung $(5.71 \%)$, Semarang (3.24\%), Surabaya (8.19\%) and Medan (3.62\%).

\section{Questionnaire}

The instruments being used in this research are referred to the previous research and the independent variables are referred to Forsyth and Danisiewicz (1985) and Porter et al., (1974), personal value is referred to Massey University, New Zealand, and the ethical judgement has applied a vignette model. However, the variables of the codes of ethics have been developed by the writer referred to the five fundamental principles of professional ethics, which is The Codes of Conduct of the Indonesian Professional Accountant (2009).

\section{Data Analysis}

Data analysis of this research has applied structural equation model (SEM) refers to Lisrel 8.72 data analysis. The structural equations of flow diagram model of personal value and ethical judgment are as follows;

$\eta_{1}=\gamma_{1} \xi_{1}+\zeta_{1}$

$\eta_{2}=\gamma_{2.1} \xi_{1}+\beta_{2.1} \eta_{1}+\zeta_{2}$

According to the aforementioned equations, two models of the measurement of exogen latent variables $\xi_{1}$ and $\xi_{2}$ and three models of the measurement of endogen latent variable which is from the indicator to latent variable $\eta_{1}$, and $\eta_{2}$ have been made. The value of loading factor, which is from the indicator to latent variable, is named lamda $(\lambda)$. Based on the aforementioned equation, the following mathematics equation of the measurement models are as follows;

a. Latent variable $\xi_{1}$ ( codes of ethics consists:

$X_{1}=\lambda x_{1.1} \xi_{1}+\delta_{1}, X_{2}=\lambda x_{2.1} \xi_{1}+\delta_{2}, X_{3}=\lambda x_{3.1} \xi_{1}+\delta_{3,} X_{4}=\lambda x_{4.1} \xi_{1}+\delta_{4}, X_{5}=\lambda x_{5.1} \xi_{1}+$ $\delta_{5}, X_{6}=\lambda x_{6.1} \xi_{1}+\delta_{6}, X_{7}=\lambda x_{7.1} \xi_{1}+\delta 7, X_{8}=\lambda x_{8.1} \xi_{1}+\delta_{8}, X_{9}=\lambda x_{9.1} \xi_{1}+\delta_{9}, X_{10}=$ $\lambda x_{10.1} \xi_{1}+\delta_{10}$, and $X_{11}=\lambda x_{11.1} \xi_{1}+\delta_{11}$.

b. Latent variable $\eta_{1}$ (personal value) consists:

$$
\begin{aligned}
& Y_{1}=\lambda y_{1.1} \eta_{1}+\varepsilon_{1}, Y_{2}=\lambda y_{2.1} \eta_{1}+\varepsilon_{2}, Y_{3}=\lambda y_{3.1} \eta_{1}+\varepsilon_{3}, Y_{4}=\lambda y_{4.1} \eta_{1}+\varepsilon_{4}, Y_{5}=\lambda y_{5.1} \eta_{1}+ \\
& \varepsilon_{5}, Y_{6}=\lambda y_{6.1} \eta_{1}+\varepsilon_{6}, Y_{7}=\lambda y_{7.1} \eta_{1}+\varepsilon_{7}, Y_{8}=\lambda y_{8.1} \eta_{1}+\varepsilon_{8}, Y_{9}=\lambda y_{9.1} \eta_{1}+\varepsilon_{9}, Y_{10}=\lambda y_{10.1} \\
& \eta_{1}+\varepsilon_{10}, Y_{11}=\lambda y_{11.1} \eta_{1}+\varepsilon_{11}, Y_{12}=\lambda y_{12.1} \eta_{1}+\varepsilon_{12}, Y_{13}=\lambda y_{13.1} \eta_{1}+\varepsilon_{13}, Y_{14}=\lambda y_{14.1} \eta_{1}+ \\
& \varepsilon_{14}, Y_{15}=\lambda y_{15.1} \eta_{1}+\varepsilon_{15}, Y_{16}=\lambda y_{16.1} \eta_{1}+\varepsilon_{16}, Y_{17}=\lambda y_{17.1} \eta_{1}+\varepsilon_{17}, Y_{18}=\lambda y_{18.1} \eta_{1}+\varepsilon_{18}, \\
& Y_{19}=\lambda y_{19.1} \eta_{1}+\varepsilon 19, \text { and } Y_{20}=\lambda y_{20.1} \eta_{1}+\varepsilon_{20} .
\end{aligned}
$$


c. Latent variable $\eta_{2}$ (ethical judgement) consists:

$\mathrm{Y}_{21}=\lambda \mathrm{y}_{21.2} \eta_{2}+\varepsilon_{9}, \mathrm{Y}_{22}=\lambda \mathrm{y}_{22.2} \eta_{2}+\varepsilon_{22}, \mathrm{Y}_{23}=\lambda \mathrm{y}_{23.2} \eta_{2}+\varepsilon_{23}, \mathrm{Y}_{24}=\lambda \mathrm{y}_{24.2} \eta_{2}+\varepsilon_{24}, \mathrm{Y}_{25}$ $=\lambda y_{25.2} \eta_{2}+\varepsilon_{25}, Y_{26}=\lambda y_{26.2} \eta_{2}+\varepsilon_{26}, Y_{27}=\lambda y_{27.2} \eta_{2}+\varepsilon_{27}$, and $Y_{28}=\lambda y_{28.2} \eta_{2}+\varepsilon_{28}$.

4. Hypothesis testing

Hypothesis testing is done by regression test and sobel mediation test. The regression test tool is used to test hypotheses $2,3 \mathrm{a}$, and $3 \mathrm{~b}$. While the sobel mediation test is used to test the hypothesis 1 . Broadly speaking, the sobel test is conducted in three stages. First, regressing the independent variable on the intervening variable. Second, regressing the independent variables and intervening variables on the dependent variable. Both steps are carried out to get the $t$ value calculated. Third, enter t value the two steps into the online formula to get the value of the sobel $t$ value. A hypothesis will be accepted if the sobel $t$ value is greater than 1.96 .

\section{RESULT}

1. Validity Test

Before the empirical data analysis is carried out, the author will test the validity of the indicators first to find out whether the indicators can really measure or reflect the latent variables tested. Validity test is done by considering the standard factor loading value of each indicator or dimension. According to Wijanto (2008: 175) validity in the form of SIMPLIS has a standard loading factor $>0.50$, another opinion states that the loading factor in each indicator has a value of $t$-value $>1.96$ then it is said to be valid (Ghozali, et al., 2014). Hair, et al., (2010: 695), states that the value of the loading factor must reach greater than 0.5 .

The following is the result of the validity test for each latent variable using lisrel 8.72 presented in the table 1 below.

Table 1. Testing the validity of indicators

\begin{tabular}{|c|c|c|c|}
\hline Indicator & $\begin{array}{c}\text { Ethical Judgment } \\
(\text { EJ) }\end{array}$ & $\begin{array}{c}\text { Codes of } \\
\text { Ethics (CE) }\end{array}$ & $\begin{array}{c}\text { Personal } \\
\text { Values (PV) }\end{array}$ \\
\hline 1 & 0.66 & 0.58 & 0.73 \\
\hline 2 & 0.70 & 0.58 & 0.51 \\
\hline 3 & 0.74 & 0.66 & 0.61 \\
\hline 4 & 0.53 & 0.69 & 0.55 \\
\hline 5 & & 0.74 & $0.47^{*}$ \\
\hline 6 & & 0.71 & $0.35^{*}$ \\
\hline 7 & & 0.69 & 0.73 \\
\hline 8 & & 0.67 & 0.59 \\
\hline 9 & & 0.68 & $0.45^{*}$ \\
\hline 10 & & $0.46^{*}$ & 0.63 \\
\hline 11 & & $0.16^{*}$ & $0.47^{*}$ \\
\hline 12 & & & 0.62 \\
\hline 13 & & & 0.63 \\
\hline 14 & & & 0.69 \\
\hline 15 & & & 0.62 \\
\hline 16 & & & 0.63 \\
\hline 17 & & & 0.59 \\
\hline 18 & & & $0.50^{*}$ \\
\hline 19 & & & 0.56 \\
\hline 20 & & & \\
\hline
\end{tabular}

Note: *invalid $(<0.5)$ 
Based on the results of testing with confirmatory factor analysis for indicators that do not meet the requirements and cannot be included in the next test are (1) code of ethics (CE10 and CE11), and (2) Personal Value (PV5, PV6, PV9, PV11, PC18.

\section{Model Testing Results}

To find out whether or not a model is fit, a model fit is assessed. The fit model assessment is done by comparing the results of the tests that have been carried out with references that are often referred to as goodness of fit. Goodness of fit is used to find out whether a model is in accordance with the model or not. Hair et al., (2014: 678), the quality of compatibility is very dependent on the characteristics of the model including sample size and complexity of the model. More complex models with large samples should not adhere to the same standard, because the sample is large and the model contains a number of measured variables and estimated parameters, the cut off value is 0.95 as an unrealistic measure of Goodness of fit. Some compatibility indexes must be used to assess the goodness of the appropriate model and must include chi square, one absolute fit index (GFI, RMSEA, or SRMR), one incremental fit index (CFI or TLI), one goodness of fit index (GFI, CFI, TLI, etc.), and one badness of fit index (RMSEA, SRMR, etc.). The result found Chi square 1,055.69/347=3.04 (good fit), RMSEA 0,084 (good fit), GFI 0.80 (good fit), NFI 0.91 (good fit), NNFI 0.93 (good fit), CFI 0.94 (good fit), IFI 0.94 (good fit), and RFI 0.90 (good fit). Thus, it can be concluded that the overall suitability of the model is good. The following shows the path diagram of the SEM and the results of the Lisrel 8.72 output for evaluating the suitability of the model presented in Figure 1 and Figure 2.

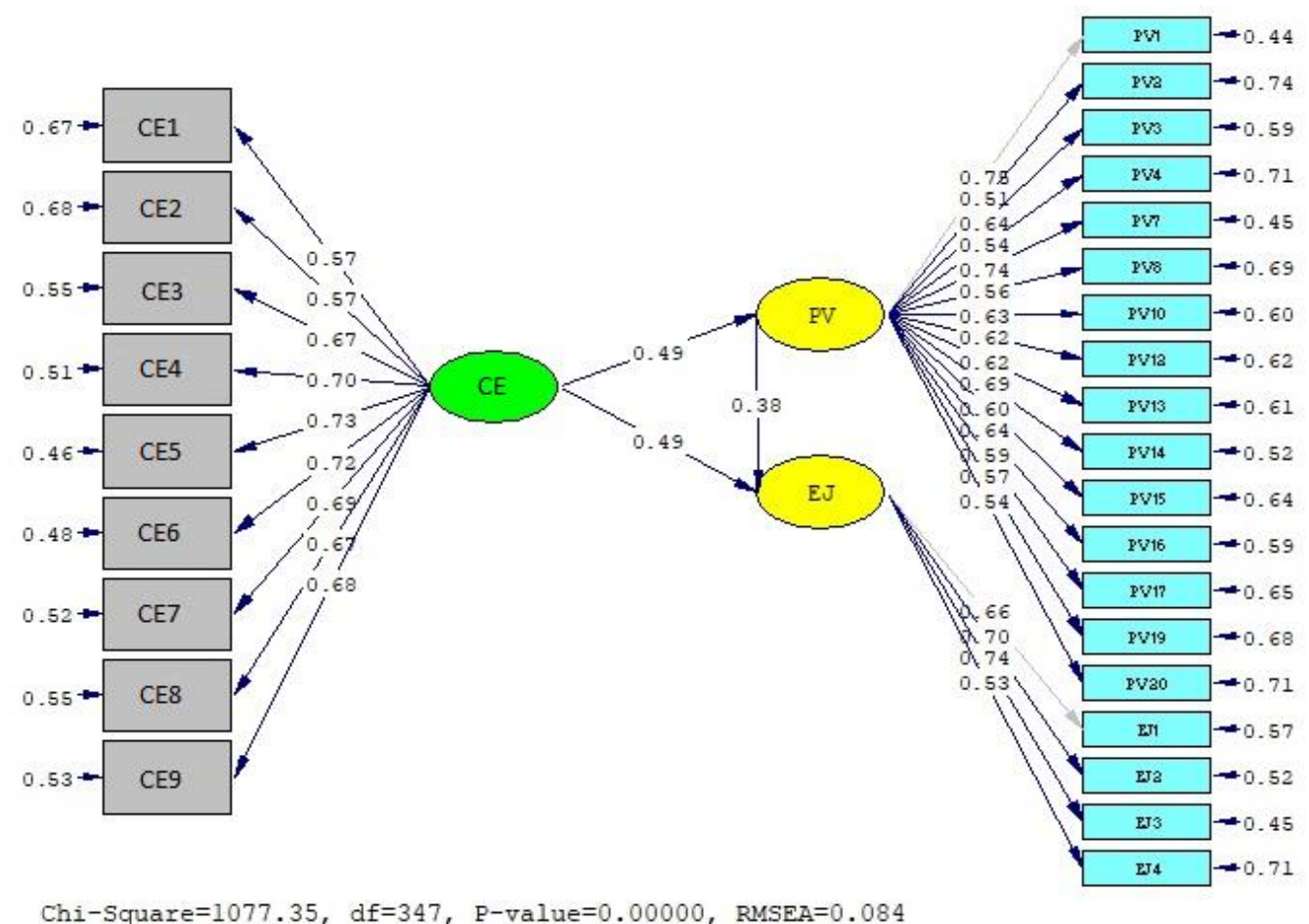

Figure 1. Standardized Loading Factor 


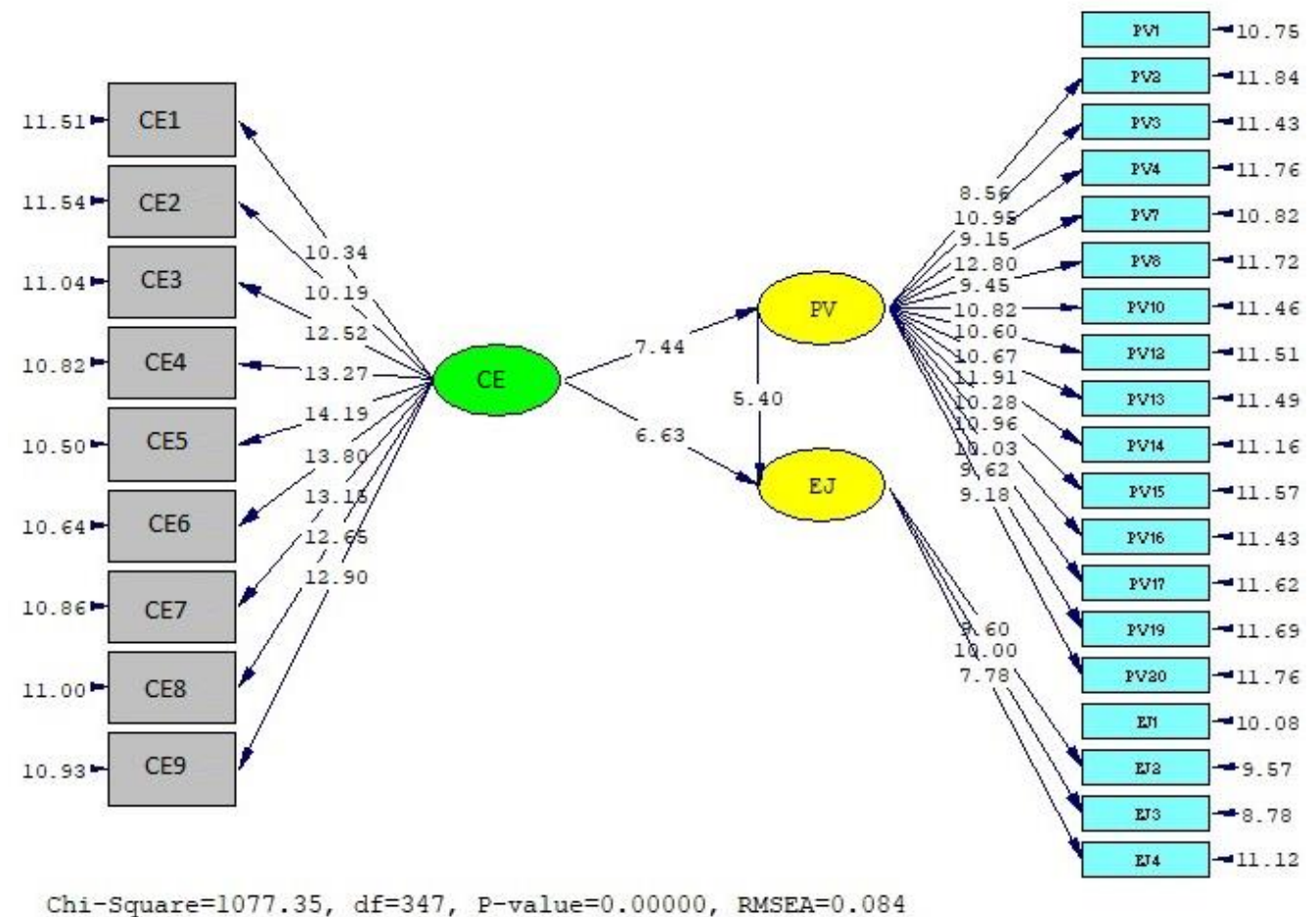

Figure 2. $t$-value

\section{Hypothesis testing}

Based on Figure 1 and Figure 2 confirm that statistically code of ethics CE) affects ethical judgment (EJ) because it has a t-value of 6.63 (t-value > 1.96) and magnitude of effect is 0.49 . Likewise, code of ethics (CE) has an effect on personal value (PV) because it has a t-value of 7.44 ( $\mathrm{t}$-value $>1.96$ ) and magnitude of effect is 0.49 . Finally, personal value (PV) affects ethical judgment (EJ) because it has a tvalue of 5.40 (t-value $>1.96$ ) and magnitude of effect is 0.38 . Based on testing the hypothesis it can be concluded that hypotheses 2, 3a, and $3 \mathrm{~b}$ are accepted. The structural equation of the results of this test is $P V=0.49 C E+e$ and $E J=0.49 C E+0.38 P V+e$.

The $\mathrm{H} 1$ hypothesis testing is done by using the sobel test online. The indirect effect of code of ethic on ethical judgment through personal value can be calculated by looking at the results of structural equations, namely the first equation $P V=0.49 C E+e$, standard error: 0.065 while the second equation $E J=0.38^{*} P V+0.49^{*} \mathrm{CE}$, standard error: 0.071 and 0.074 .

\section{Sobel Test}

Based on the coefficients and standards of errors contained in the two equations, it can be tested whether the personal value mediates of code of ethics on ethical judgment? Based on testing with Sobel Test online by (a) entering the variable coefficient code of ethics on personal value 0.49 with standar error 0.074 and (b) entering the variable coefficient of personal value on ethical judgment 0.38 with standar error 0.071 . The results is the effect codes of ethics on ethical judgment through personal value is sobel test statstic: 4.16243643, one-tiled probability: 0.00001574 , and two-tiled probability: 0.00003149 . Based on these results it can be concluded that the personal value variable can mediate the code of ethics towards ethical judgment, meaning that code of ethics influences ethical judgment through personal value, because the value of $t$ value $>t$ table, namely $4.16243643>1.96$ and significant at alpha $5 \%$. 


\section{Discussion}

a. The codes of ethics affecting the ethical judgement thru personal value intervention.

Barsky, A. E. (2010: 2), states ethics and values are two different but interrelated things. Value refers to the ideals of a person, family, group, organization, or community. Whereas, ethics refers to rules that determine what type of behavior is appropriate and what type of behavior is inappropriate. Karajeh (2004), states that the professional ethics of public accountants have played an important role in increasing the trust of users of financial statements, to confirm the integrity of financial statements.

The test results show that the code of ethics influences the personal value of public accountants. This reveals that a public accountant increasingly understands the professional code of ethics in carrying out audits causes the personal value of accountants to increase. Likewise, the accountant's code of ethics on ethical considerations reveals that the more understanding the professional code of ethics of an accountant will ethically consider the opinion of the results of his work. This result is in line with Pflugrath et al. (2007), revealed that the existence of a code of ethics has a positive impact on the quality of judgments made by professional accountants, this indicates that the code of ethics leads to the quality of judgment of public accountants.

This result is also, in line with what was conveyed (Baird and Zelin, 2007), that personal value can encourage it to behave ethically or unethically. Gulla, A (2010), states that personal values are a combination of various beliefs and understandings of human relations. A person can well understand the values of people in knowing their behavior in certain situations. If personal responses and decisions are based on truth, compassion, love and respect for others, this shows that we are useful to others. Personal values that create an impact. It is desirable to understand how personal values can be modified to create better conditions.

b. The codes of ethics upon the ethical judgement

The acceptance of the hypothesis has provided an empirical evidence explaining that the ethics refers to the Indonesian Accountants understanding about the principles of the accountant fundamental codes of ethics which is integrity, objectivity, competency, accuracy, carefully, professionally, confidentiality, and professional behavior that can affect a decreasing of the ethical judgement of the accountant related to the opinion required.

The result of this research is getting along with the previous research done by Plugrath et el., (2007) indicated that the existence of codes of ethics has positively affected the quality of judgement provided by the professional accountant. It is explaining that codes of ethics in a broader context have complied with the experience pursuing the higher quality of judgement. Wibowo (2010) described that there has been a different understanding about the professional codes of ethics between women's auditor and men's auditor, and the understanding codes of ethics affecting the auditor judgement. Zakaria et al., (2015) determined that the understanding codes of ethics has statistically and significantly affected the ethical judgement thru the perception of ethics issue. It means that the understanding codes of ethics is very crucial for the accountants to solve the ethical problems at working area. Ziegenfuss and Martinson (2002) described that the understanding codes of ethics has affected significantly the personal ethical perception and judgement. Wibowo (2010) described that the understanding codes of ethics has affected the auditor judgement.

Based on the aforementioned result of the research and the previous researches, it can be described that the more understanding codes or ethics, the 
better accountants will be doing their functions and tasks providing the ethical judgement. The result of this research is in compliance with the theory of deontology defining that an action is good or ethical when it has been conducted due to the responsibility to work on it instead of the consequence of the result of an action happened.

The result of this research has been affecting the accountants in Indonesia in order to make them understand the professional codes of ethics so that they can perform their tasks and responsibilities as the accountants who can make a decision according to the ethics. Respecting codes of ethics is expected to be able to make them professional accountants who are not only competent in their tasks but also consider the ethical value. Ethical consideration will be different from one to another due to the ability to understand codes of ethics resulting different judgments provided.

c. The codes of ethics upon the personal value

The acceptance of this hypothesis has provided an empirical evidence regarding the understanding codes of ethics for the Indonesian Accountants which is in this research they have been represented by partners, managers, supervisors and senior accountants refers to the principles of the accountant codes of ethics which is the principles of integrity, objectivity, professional competency, professional accuracy and carefulness, confidentiality, and professional behavior that can affect the personal value of the accountants.

The fundamental principles of codes of ethics should have to be absolutely recognized by the accountants though their effect against the personal value. The fundamental principles that should have to be understood is mentioned on the Guideline of Codes of Ethics of the Indonesian Professional Accountants, which is as follows;

1) Integrity principles, professional accountant should have to be clear and honest in relation with the business and professional relationship performing the tasks.

2) Objectivity principles, professional accountant should not have been dealing with the subjectivity, conflict of interest or undue influencing from the other parties affecting the professional and business judgement.

3) Competency, accuracy and due care principles; professional accountant is obliged to keep the professional knowledge's and skills according to the level required continuously, so that the clients or the employers could receive the professional services provided which is in compliance with the recent evolvement, regulations, and method of the job execution. The accountant should have to work professionally and in compliance with the applicable of professional standard and professional codes of ethics.

4) Confidentiality principles; professional accountants is obliged to keep the secret of the information provided as the result of the professional and business relationship, and is not allowed to discover the related information to the third party without any agreement from the client or employer, unless there is an obligation to discover it required by laws or other applicable regulations. Any confidential information obtained due to the professional and business relationship is not permitted to be used by the professional accountants for their own benefit or other third-party benefit.

5) The principles of professional behavior, the professional accountants are obliged to respect the applicable laws and regulations and to avoid any activity, which can discredit their professionalism.

\section{d. Personal value upon ethical judgment}

This research has involved the public accountant respondents, which is partners, managers, supervisors and senior accountant at the big five of the cities, Jakarta, Bandung, Semarang, Surabaya and Medan. The result of empiric test is in 
line with the result determined by Alteer et al. (2013) defined that the personal value has not directly affected the ethical judgement, but it has affected thru the ethical sensitivity. This result is getting along with the research of Sauder and Wenzel (2008) indicated there is not any effect of personal value occurred upon the ethical judgment accordingly. Nevertheless, this result is different from the research of Alleyne et al (2013) determined that the personal value has been positively affecting the ethical behavior of accountancy students as the respondents and non-accountancy ones. Vitell and Hidalgo (2006) indicated the ethical corporate value is the most important issue for business ethics and social responsibility, but Ziegenfuss and Martinson (2002) determined that the personal ethical philosophy has not had a significant effect. Kung, Fan-Hua and Cheng $\mathrm{Li}$ Huang (2013) determined that the value preference could not be the predictor of ethical belief. However, on the contrary, the personal value has affected the ethical belief thru moral philosophy.

The difference of this research with other previous ones indicated that distinctive culture at each country has happened due to the distinction of western culture and eastern which is whatever the European people think something is ethic, but the eastern people think it is not. Refers to Robins (2006), there is not any ethical standard globally.

\section{MAIN FINDINGS}

1. Codes of ethics has a positive effect on ethical judgment, mediated by personal values, revealing that the more understanding the professional code of ethics, the more it will influence the increase in ethical judgment of public accountants.

2. Codes of ethics has a positive effect on ethical judgment which means that this shows that the higher the understanding of professional ethics of public accountants, the higher the ethical judgment of public accountants in considering opinions, opinions, or decisions given in carrying out their duties.

3. Codes of ethics has a positive effect on personal value, which means that this shows the more understanding the professional code of ethics, the individual values contained in a public accountant associated with understanding the professional code of ethics will increase.

4. Personal value has a positive effect on ethical judgment, which means that this shows the higher the personal value of each individual public accountant, the higher the ethical judgment of the individual.

5. Personal value Personal value is proven to be an intervening variable, this proves that the better the personal value of an accountant will be better in providing ethical judgment

\section{LIMITATION}

Some limitations of this research should have to be solved and these limitations can be used to develop the future similar research. The limitations are as follows;

1. This research has applied the questionnaire, which might bias the respondents' responses.

2. This research is focus at the big five of the cities, Jakarta, Bandung, Semarang, Surabaya and Medan. It might be dealing with a different characteristic of the respondents. Therefore, this research cannot be generalized for all the accountants in Indonesia.

3. The questionnaire applied is referred to Forsyth and Danisiewics (1985) and Porter et al (1974) related to the independent variable, Massey University New Zealand (2015) related to the personal value variable and Forsyth and Danisiewicz (1985) related to 
the ethical judgement variable, which might not comply with the condition of the accountants in Indonesia.

\section{CONCLUSION}

The result of this research has indicted that the codes of ethics has been affecting the personal value and the ethical judgement accordingly. It is expected to provide a positive implication for a public accountant (partner, manager, supervisor and senior accountant) to understand more about the professional codes of ethics. Based on this research, accountants should have understood the professional codes of ethics better. Moreover, they have to improve more their knowledge and to explore more the factors affecting the ethical judgement instead of the variables measured in this research. Therefore, they will be making a judgement based on the better ethical consideration.

\section{REFERENCES}

Abdolmohammadi , M.J . and C. R. Baker. (2005). Accountants' value preferences and moral reasoning. Journal of Business Ethics, 69(1): 11-25.

Akaah, I. P., and Lund, D. (1994). The influence of personal vand organizational values on marketing professional' ethical behavior, Journal of Business Ethics, Vol 13, pp. 417-30.

Alleyne, P; McClean, C. C.; and Harper, A. (2013). Examining personal value and ethical behaviour perception between accounting and non-accounting students in the Caribbean. The Accounting Education' Journal. 13. 47-70.

Alteer, A. H., Yahya, S. B., and Haron, M.M. (2013). Auditors' personal values and ethical judgement at different levels of ethical climate: A Conceptual Link, Journal of Asian Scientific Research, 3(8):862-875.

$\mathrm{Au}, \mathrm{A}$., \& Wong, D. (2000). The impact of guanxi on the ethical decision-making process of auditors - an exploratory study of Chinese CPAs in Hong Kong. Journal of Business Ethics, 28 (1) (November), 87-93.

Baird, J dan Zelin, R. (2007). Personal value and ethical viewpoints of accounting Majors: How do they compare to other students? Journal of Legal, Ethical and Regulatory Issue. 10 (2): 39-55.

Barsky, A. E. (2010). Ethics and values in social work. Oxford University Press, New York.

Booth, Peter dan Schulz, Axel K-D. (2004). The impact of an ethical enviroment on manager's project evaluation judgment under agency problem condition, 29 (11):473-488.

Brief, A. P., Dukerich, J. M., Brown, P. R., dan Brett, J. F. (1996). What's wrong with the treadway arencommission report? Experimental analyses of the effects of personal values and codes of conduct on fraudulent financial reporting, Journal of Business Ethics 15, 183-198.

Coleman, M., Kreuze, J., Langsam, S. (2004). The new scarlet letter: Student perceptions of the accounting profession after Enron. Journal of Education for Business, 79 (3), 134-141.

Yuli Anwar. Intervening effect of personal value on code of ethics to ethical judgment 
Douglas E. Ziegenfuss, Otto B. Martinson, (2002) "The IMA code of ethics and IMA members' ethical perception and judgment", Managerial Auditing Journal, Vol. 17 Issue: 4, pp.165-173.

Finegan, J. (1994). The impact of personal value on judgments of ethical behavior in the workplace, Journal of Marketing, Vol 49, pp. 87-96.

Ghozali, I. (2011). Application of multivariate analisys by SPSS, Fourth Print, Issueing Agency Universitas Diponegoro, Semarang.

Ghozali, I. (2013). Model persamaan struktural: Konsep dan aplikasi dengan program AMOS 21.0, Cetakan Kelima, Badan Penerbit Universitas Diponegoro, Semarang.

Gulla, A. (2010). creating values in life: personal, moral, spiritual, family and social values, author house, Bloomington, Indiana.

Hair, J. F.; Black, W. C.; Babin, B. J. and Anderson, R. E. (2014). Multivariat data analysis, Seventh Edition, Pearson Prentice Hall, New Jersey.

Herron, T. L. and Gilbertson, D. L. (2004). Ethical principles vs. ethical rules: the moderating of moral development on audit independent judgements. Business Ethics Quarterly, 14 (3): 499-523.

Indonesian Institute of Certified Public Accountants. (2009). Code of conduct of Indonesian professional accountant, Salemba Empat, Jakarta.

Indriantoro, N. and Supomo, B. (2014). Business research methodology for accounting \& management, First Edition, Second Print, BPFE, Yogyakarta.

Jones, J., Massey, D. W. and Thorne, L. (2003). Auditors' ethical reasoning: insights from past research and implications for the future, Journal of Accounting Literature, Vol. 22, pp. 45-103.

Jones, T. M. (1991). Ethical decision-making by individuals in organizations: an issuecontingent model, Academy of Management Review, Vol. 16 No. 2, pp. 366-95.

Karacaer, S., R. Gohar, M. Aygün and C. Sayin. (2009). Effects of personal values on auditor's ethical decisions: A comparison of Pakistani and Turkish professional auditors. Journal of Business Ethics, 88(1): 53-64.

Karajeh, A. A. A. H. (2004). How far external auditors are committed to code of conduct in jordan, and the ways which encourage them to follow professional behavior. In: Accounting. Amman Arab University Amman.

Kung, Fan-Hua and Huang, Cheng Li. (2013). Auditors' moral philosophies and ethica beliefs. Department of Accounting, Tamkang University, Taipei, Taiwan. Management Decision Vol. 51 No. 3, pp. 479-500.

Nur, Emrinaldi D. P. et al. (2014). Effects of ethics, competence, auditor experience and audit situations on the accuracy of providing audit opinions through auditor materiality and skepticism considerations, Jurnal Forum Bisnis dan Kewirausahaan, Vol. 3 No. 2 Maret 2014.

Pflugrath, G; Bennie, N. M.; and Chen, L. (2007). Causal effects of regulatory, organizational and personal factors on ethical sensitivity, Journal of Business Ethics, 30 (6): 123-59. 
Shafer, W. E., Morris, R. E. and Ketchand, A.A. (2001), Effects of personal values on auditors' ethical decisions, Accounting, Auditing \& Accountability Journal, Vol.14 No. 3, pp. 254-77.

Wibowo, Ery. (2010). Penagaruh gender, pemahaman kode etik profesi akuntan, terhadap auditor judgment, Media Akuntansi Unimus, 1 (9).

Wijanto, S. H. (2008). Structural equation modeling dengan Lisrel 8.8, Graha IImu, Yogyakarta.

Wiratama, William Jefferson and Ketut Budiartha. 2015. Effect of independence, work experience, due professional care and accountability on audit quality. Jurnal Akuntansi. ISSN 2302- 8578.

Wright, G. B., Cullinan, C. P. dan Bline, D. M. (1997). The rellationship between an individual's values and perceptions of moral intensity: an empirical study, Behavioral Research in Accounting, Vol. 9 Supplement, pp. 26-40.

Zakaria, M; Haron, H. and Ismail, I. (2010). Knowledge of ethics, perceived ethical problems and ethical judgments. Journal of Financial Reporting and Accounting, 8 (1): 50-64. 
The Accounting Journal of BINANIAGA Vol. 05, No. 01, June 2020

p-ISSN: 2527-4309, e-ISSN: 2580-1481

$5^{\text {th }}$ Accreditation Rating: January 14, 2019 - January 13, 2024

This page intentionally be emptied.

Yuli Anwar. Intervening effect of personal value on code of ethics to ethical judgment

Page : 32 